$\begin{array}{ll}\text { Abstracta Iranica } & \begin{array}{l}\text { Abstracta Iranica } \\ \text { Revue bibliographique pour le domaine irano-aryen }\end{array} \\ & \text { Volume } \mathbf{2 9} \mid \mathbf{2 0 0 8} \\ & \text { Comptes rendus des publications de } \mathbf{2 0 0 6}\end{array}$

\title{
Le paradoxe iranien. Paris, Robert Laffont, 2006.
}

\section{Gilles Riaux}

\section{OpenEdition}

Journals

Édition électronique

URL : http://journals.openedition.org/abstractairanica/32692

DOI : 10.4000/abstractairanica.32692

ISSN : 1961-960X

Éditeur :

CNRS (UMR 7528 Mondes iraniens et indiens), Éditions de l'IFRI

Édition imprimée

Date de publication : 15 mai 2008

ISSN : 0240-8910

\section{Référence électronique}

Gilles Riaux, «Le paradoxe iranien. Paris, Robert Laffont, 2006. », Abstracta Iranica [En ligne], Volume 29 | 2008, document 387, mis en ligne le 15 septembre 2008, consulté le 26 septembre 2020. URL : http://journals.openedition.org/abstractairanica/32692 ; DOI : https://doi.org/10.4000/ abstractairanica.32692

Ce document a été généré automatiquement le 26 septembre 2020.

Tous droits réservés 


\title{
Le paradoxe iranien. Paris, Robert Laffont, 2006.
}

\author{
Gilles Riaux
}

Cet ouvrage non académique a la grande qualité de vulgariser nombre des travaux scientifiques publiés sur la société iranienne contemporaine. Certes l'absence de renvois à ces travaux peut sembler gênante, mais les contraintes posées par l'édition de ce type de livre l'expliquent grandement. L'A. commence par présenter les principales évolutions socio-démographiques qui ont contribué à transformer profondément la société post révolutionnaire, en dépit de la fermeture de la sphère politique aux nonislamistes. Ensuite, l'A. se concentre sur le système politique et tente d'expliquer la montée en puissance du clan des ultra-conservateurs que marque l'élection de Mahmoud Ahmadinejad à la Présidence de la République en 2005. Enfin, l'analyse se concentre sur la question du nucléaire et les enjeux qu'elle pose tant à la sécurité internationale qu'à la société iranienne. On pourrait reprocher à l'ouvrage d'adopter un point de vue trop téhéranais que ne vient enrichir qu'une courte escapade sur la Caspienne.

INDEX

Thèmes : 13.1. Iran 
AUTEURS

GILLES RIAUX

Paris 